\title{
Bioeconomic assessment of a change in fishing gear selectivity: the case of a single-species fleet affected by the landing obligation
}

\author{
Raúl Prellezo, Itsaso Carmona, Dorleta García, Luis Arregi, Jon Ruiz, Iñigo Onandia
}

\author{
AZTI, Txatxarramendi ugartea z/g, 48395 Sukarrieta, Bizkaia, Spain. \\ (RP) (Corresponding author) E-mail: rprellezo@azti.es. ORCID iD: http//orcid.org/0000-0001-5998-8146 \\ (IC) E-mail: icarmona@azti.es. ORCID iD: http://orcid.org/0000-0001-6383-2566 \\ (DG) E-mail: dgarcia@azti.es. ORCID iD: http://orcid.org/0000-0002-5090-4054 \\ (LA) E-mail: larregi@azti.es. ORCID iD: http://orcid.org/0000-0001-6273-3654 \\ (JR) E-mail: jruiz@azti.es. ORCID iD: http://orcid.org/0000-0003-0717-0136 \\ (IO) E-mail: ionandia@azti.es. ORCID iD: http://orcid.org/0000-0002-7844-8046
}

\begin{abstract}
Summary: The European Union Common Fisheries Policy has established a discard ban, which states that fish below a reference size cannot be sold directly for human consumption. In a fishing effort-regulated fishery, the discard ban can result in extra handling, storing and landing costs. In an output-regulated fishery, this policy might also limit the effort levels as all the catches count against the quota. In both cases, this regulation can reduce the economic performance of the companies, even in single-species fisheries. A possible solution is to increase the mesh size, thus retaining fewer small individuals. To study this option, a bioeconomic simulation of a change in the gear selectivity from 100- to 120-mm minimum mesh size (MMS) was performed. The results show that the private perspective (profits) does not change. Furthermore, due to the lower retention of $120 \mathrm{~mm}$ MMS, the efficiency of a fishing day was reduced by $5 \%$ and $2.5 \%$, from the point of view of capital and labour productivity, respectively. In contrast, gross revenues increased by $1.5 \%$ and crew compensation by $2 \%$. Given a societal benefit of this change in the mesh size, this gain could be re-distributed to provide an incentive for selectivity improvements.
\end{abstract}

Keywords: minimum mesh size; landing obligation; minimum conservation reference size; simulation model; selectivity; hake.

Evaluación bioeconómica del cambio en la selectividad de un arte de pesca: el caso de una flota mono-específica afectada por la obligación de desembarque

Resumen: La Política Pesquera Común de la Unión Europa ha introducido la prohibición de descartar, estableciendo que todo pescado por debajo de una talla de referencia no puede ser vendido para consumo humano directo. En una pesquería regulada a través de limitaciones del esfuerzo de pesca, la prohibición de descartar puede generar sobrecostes de manipulación, almacenamiento y desembarque adicionales. En una pesquería regulada a través de límites en las capturas, esta política podría incluso limitar los niveles de esfuerzo ya que todas las capturas deben ser deducidas de la cuota. En ambos casos, esta regulación puede reducir el resultado económico de las empresas, incluso en el caso de una pesquería mono-específica. Una posible solución sería aumentar el tamaño mínimo de la malla, y así reducir la retención de los individuos más pequeños. Con el fin de estudiar esta opción, se ha realizado una simulación bioeconómica de un cambio en el tamaño mínimo de la malla de 100 a 120-mm. Los resultados muestran cómo la perspectiva económica privada (beneficios) no varía. Más aun, debido a la menor retención de la malla de $120 \mathrm{~mm}$, la eficiencia de un día de pesca se ve reducida en un $5 \%$ y en un $2.5 \%$, desde el punto de vista de la productividad del capital y del trabajo, respectivamente. Por el contrario, los beneficios brutos aumentan un $1.5 \%$ y la remuneración al trabajo en un $2 \%$. Debido a la existencia de un beneficio social, la ganancia podría ser redistribuida para así ofrecer un incentivo a esta mejora de la selectividad.

Palabras clave: tamaño mínimo de la malla; obligación de desembarque, talla mínima de referencia a efectos de conservación; modelo de simulación; selectividad; merluza.

Citation/Como citar este artículo: Prellezo R., Carmona I., García D., Arregi L., Ruiz J., Onandia I. 2017. Bioeconomic assessment of a change in fishing gear selectivity: the case of a single-species fleet affected by the landing obligation. Sci. Mar. 81(3): 371-380. doi: http://dx.doi.org/10.3989/scimar.04597.18A

Editor: P. Martín.

Received: December 19, 2016. Accepted: April 27, 2017. Published: July 4, 2017.

Copyright: (C) 2017 CSIC. This is an open-access article distributed under the terms of the Creative Commons Attribution (CC-by) Spain 3.0 License. 


\section{INTRODUCTION}

Discards are defined as the proportion of the total organic material of animal origin in the catch that is thrown away or dumped at sea, for whatever reason (FAO 1996). Article 15 of the EU Common Fisheries Policy (CFP) (EU 2013) bans discards, at least partially. This discard ban has been called the landing obligation (LO): within a predefined time frame, all the catches of stocks subject to a total allowable catch (TAC) regulation must be landed. Additionally, fish under a minimum conservation reference size (MCRS) cannot be used for human consumption. Such fish can only be sold for fish meal, pet food or other products not destined for direct human consumption.

The MCRS has been established as the means of controlling fish mortality by age group. The length of the fish can be used as an indirect indicator of age (Cotter and Pilling 2007). The length distribution of a given species in the catch is related to the fishing gear and its technical selectivity characteristics (Hovgård and Lassen 2000). Catching undersized fish is the result of a mismatch between the selectivity of the gear and the MCRS and can occur even in highly species-selective fishing activities.

The LO is likely to have some effect on the fishing activity. One of its consequences is the choke species effect (Schrope 2010). Under LO, in a multispecies fishery, the TAC for one species will restrict the overall effort deployed by a fleet, and hence the total catches of other species. However, this choke effect is not unique to a multispecies fishery. In a single-species fishery managed using a TAC system, catches and landings should be the same. All catches, including those under the MCRS, count against the quota but some cannot be sold for direct human consumption. It implies that a single species can be "choked" by unfavourable length distribution of the catches (MCRS choke effect).

Reducing the choke effect in a single-species fishery implies reducing the caches of individuals below the MCRS. The first objective of this study was to explore, in consultation with the skippers, the measures that could reduce this choke effect. Governance is key in fishery management, especially when a complex measure such as the LO is implemented. The effects of this measure, its implementation and its legitimacy affect compliance with and attainment of objectives (Brookhuis 2015). It is important to obtain the opinions of the skippers and consider their proposals for the alleviation of the undesired outcomes of the LO. The skippers consulted put forward a potential solution: an increase in the MMS of the trawl cod-end. In fact, this is discarding mitigation practice number 5 of the 12 described in Sigurðardóttir et al. (2015). However, during the consultation, the fishermen also requested an impact assessment of the likely consequences of increasing the MMS. Due to the complex, nonlinear nature of fishery systems, these consequences are not easy to evaluate. A study by Suuronen and Sardà (2007) reports that the biological benefits might not be as significant as expected, highlighting the need for biological assessment of the MMS change. The study of Suuronen and Sardà recommends a costbenefit analysis of any change in technical measures before they are implemented.

The MCRS choke effect is not the only cost that can be anticipated as a result of the LO. The obligation to retain all the catches means that the storing capacity of the vessel(s) must be considered. If its limit is reached within one trip, more trips might be required to land the appropriate amount of fish. Additional crew effort, handling and landing costs (the landings not destined for human consumption have to be treated in a different manner) must also be considered. However, part of these costs can be recovered by selling the catch as non-human consumption products, such as fishmeal.

An impact assessment, the core of the rationale of the LO regulation, was the second objective of this study. The LO should, ideally, create economic incentives to use the new or already available technology to maximize the catches that can be used for human consumption. This should be done by considering the sustainability prescription provided by the Maximum Sustainable Yield (MSY) objective (Article 2.2 of the CFP [EU 2013]).

Only a few studies analyse the cost-benefit of a selectivity change (Heikinheimo et al. 2006, Macher et al. 2008). The published results are very case-specific, reinforcing the need to assess the likely effect of a mesh-size change case by case, as pointed out by Suuronen and Sardà (2007).

In an impact assessment, the different dimensions of the system (economic, biological and social) cannot be treated in isolation. Any biological effects on, for example, the productivity of the stock (Escapa and Prellezo 2003, Garcia et al. 2011), will affect the economic performance of the fleets (Garcia et al. 2011). Moreover, if economic and/or financial consequences for the companies are foreseen, this prediction might trigger a reaction and hence change the catch levels and composition (Simons et al. 2015). This means that the simulations must be fully coupled and integrated; biological effects change the results of fishing companies, and the reaction of the fleets affects the dynamics of the stocks.

To perform a biological and economic impact assessment of changing the mesh size, we used a bioeconomic stochastic simulation model of a hake fishery in the Bay of Biscay. The simulation was based on an age-structured model for hake and focused on a single fleet targeting hake (Merluccius merluccius) in this area. The model produces indicators over the simulation period such as biomass, catches, landings, discards, revenues and profits. The results led to some interesting conclusions concerning the economic and social incentives for changing the mesh size.

\section{MATERIAL AND METHODS}

\section{Overview of the pair-trawler hake-directed fishery}

The Bay of Biscay (Fig. 1) is an ecosystem in which the fishing fleets from eight EU member states are active (France, Spain, Germany, Denmark, United Kingdom, Ireland, the Netherlands and Portugal). In 2013, 


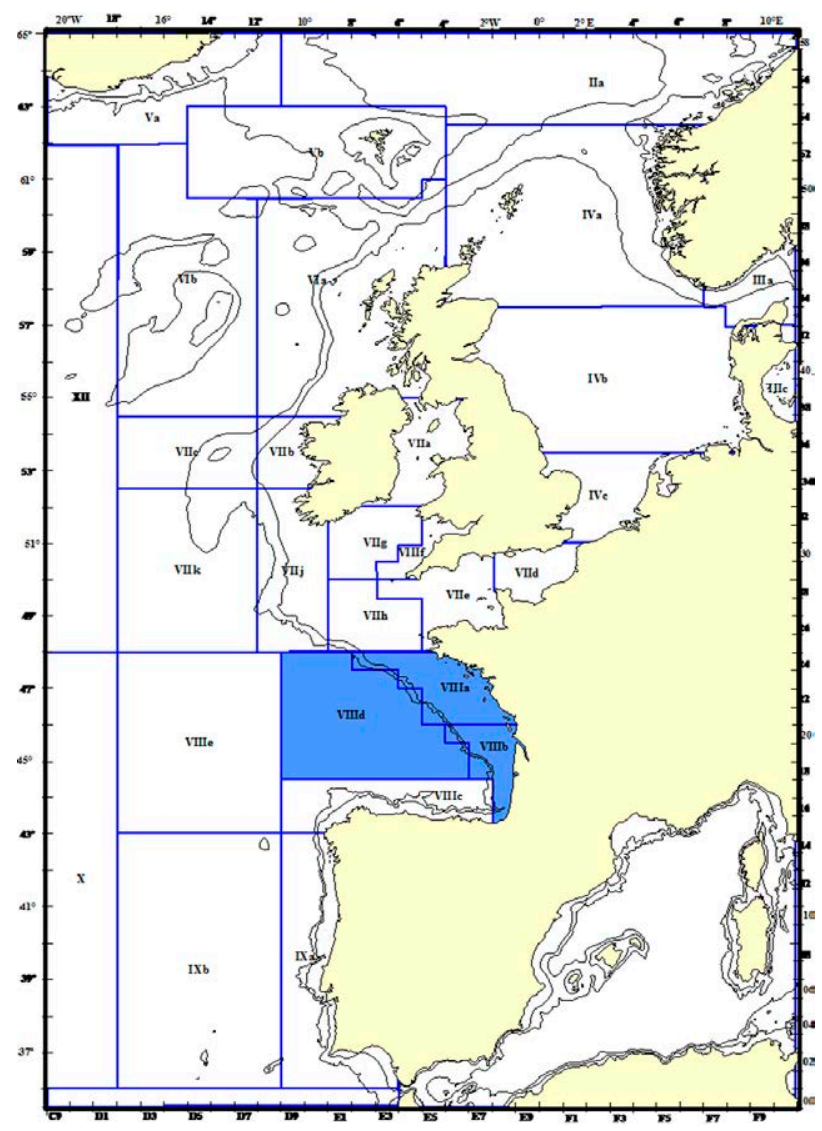

Fig. 1. - Case study area: Bay of Biscay (shaded area).

the French and Spanish fleets accounted for $93 \%$ of the total catches in this area (ICES 2014).

Many extended and diverse communities of commercial species can be found in the Bay of Biscay and surrounding waters (ICES 2014). In the demersal group, the most important commercial species are hake, megrim, anglerfish and sole. These species account for approximately $50 \%$ of the fish biomass.

Hake is important due to its abundance and economic value. It can live for as long as 20 years and reach a length of $140 \mathrm{~cm}$ and a weight of $15 \mathrm{~kg}$. It reaches its sexual maturity at around three to four years of age. It is usually found at a depth of between 75 and $400 \mathrm{~m}$. It tends to stay close to the seabed in daytime, leaving it to swim up the water column only at night.

There are two (management) stocks of hake in Atlantic EU waters. The northern stock (the stock targeted by the fleet analysed) is found in the North Sea, Skagerrak, on the Atlantic coast of the UK and Ireland, and in the Bay of Biscay.

The management of hake in the Bay of Biscay is based on a TAC and quota system. An MCRS of $27 \mathrm{~cm}$ is in place for the Atlantic waters $(30 \mathrm{~cm}$ for in Kattegat and Skagerrak the MCRS is of $30 \mathrm{~cm}$ and in the Mediterranean of 20). Hake is normally a part of a mixed fishery with other demersal species such as anglerfish and megrim and pelagic species such as mackerel and horse mackerel.

The Spanish bottom pair trawlers operating in the Bay of Biscay are an exception to this multispecies characteristic. In the years 2011-2013, this fleet consisted of 10 vessels (5 fishing units, each consisting of two paired vessels) operating exclusively in the Bay of Biscay, with an average length of $38 \mathrm{~m}$. Their average freezer storage capacity was 8600 (4300 per vessel) 12-kg boxes (the characteristic box type used by this fleet). On average, their fishing effort was distributed among 50 trips (per fishing unit and year). They captured approximately $8 \%$ of the total northern stock and $25 \%$ of hake catches in the Bay of Biscay.

The vessels in this group use a very high verticalopening bottom net (MMS of $100 \mathrm{~mm}$ ) and target mainly hake. This species accounts for $90 \%$ of the landings and approximately the same proportion of income (Fig. 2) of the bottom pair-trawler fleet. It can therefore be considered a single-species fleet; this means that under $\mathrm{LO}$, the effort is not going to be limited by any other species. However, the effort constraint might arise from the fact that approximately $5 \%$ of the catches of hake (in weight) are individuals under the MCRS. In the past, the fish smaller than the MCRS were discarded. Furthermore, according to Rochet et al. (2014), 99\% of hake discards consist of individuals under the MCRS. Under the provisions of the LO, from 2016 onwards, such fish must be landed and counted against the quota.

\section{Selectivity calculations}

Before assessing the impact of a change in the MMS, the extent of the size change must be chosen. The five skippers who took part in the survey requested that the MMS be increased from 100 to $120 \mathrm{~mm}$.

It should also be noted that this selectivity level is specific for hake, and the changes do not affect the catches of other species. This might be a problematic assumption in the multispecies fisheries, but the fleet analysed here targets only hake, so; this assumption should not significantly affect the results.

To simulate the selectivity change, it was considered that the catchability $(q)$ can be decomposed into a product of the selectivity of the gear used and a parameter that incorporates the vulnerability, accessibility and availability of the fish, as described in the paper of Arreguín-Sánchez (1996). Mathematically,

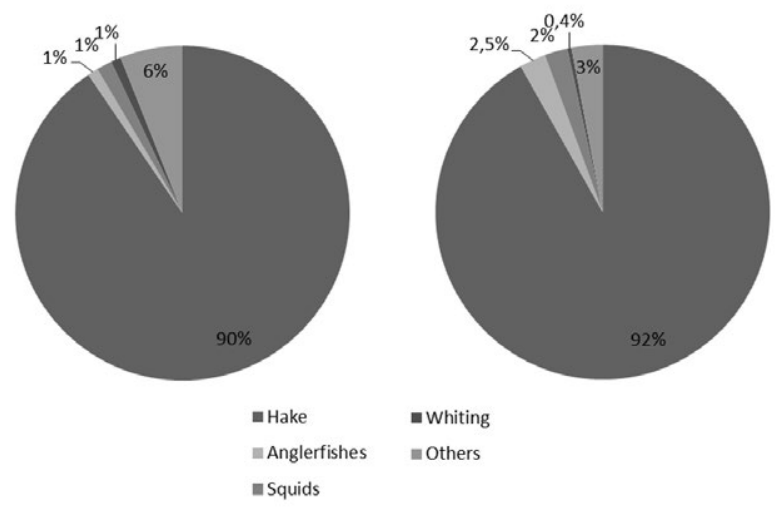

Fig. 2. - Landings (left) and income (right) composition for pair trawlers. Average for 2011-2013. 


$$
\mathrm{q}_{\mathrm{a}, \mathrm{ms}}=\mathrm{S}_{\mathrm{a}, \mathrm{ms}} \mathrm{r}_{\mathrm{a}} \text {, }
$$

where $S_{a, m, s}$ stands for the selectivity of fish of age a related to the MMS; $m$ s and $r_{a}$ stand for the factors affecting catchability and are not related to the MMS. If the catchability and selectivity at age a for a given MMS are known, $r_{a}$ can be calculated by applying Equation 1. It can be used afterwards to estimate the hypothetical catchability for the MMS, for which age selectivity is known.

Selectivity of the fish length for pair trawlers with 100-mm MMS has been estimated by The Spanish Oceanography Institute (IEO 2006). In the same study, the selectivity of $80-\mathrm{mm}$ MMS was also provided. A logistic selection curve (Eq. 2) was fitted to the results for the 100-mm MMS.

$$
r(L)=\exp (a+b L) /(1+\exp (a+b L))
$$

where $\mathrm{a}$ and $\mathrm{b}$ are the parameters to be estimated. The results of the estimation were $a=-6.53$ and $b=0.2$. This curve has the property that the length for $50 \%$ retention $r\left(L_{50}\right)$ is such that $r\left(L_{50}\right)=0.5$ and therefore $L_{50}=-a / b$.

However, there are no studies providing the length selectivity for hake for pair trawlers with 120-mm MMS. Furthermore, several factors affect the size selection of the towed fishing gears for a given mesh size. These are the spatial and seasonal variations (Ozbilgin and Wardle 2002), gear design, netting materials and twine diameters (Herrmann 2005). Vessel-level factors also affect the cod-end selectivity (Tschernij and Holst 1999). All these factors explain the large variability in the results of size selection experiments with towed fishing gears.

To overcome these difficulties, the percentage change in $\mathrm{L}_{50}$ between 80- and 100-mm MMS was calculated. It was used as a proxy of the $\mathrm{L}_{50}$, keeping the shape of the curve (parameter b of Eq. 2) constant.

The results showed that the $\mathrm{L}_{50}$ was $22.6 \mathrm{~cm}$ with an 80-mm MMS $34.6 \mathrm{~cm}$ with a 100-mm MMS. Consequently, it could be inferred that the $\mathrm{L}_{50}$ for a 120mm MMS was $40.8 \mathrm{~cm}$. This last value was within the range of the expected $\mathrm{L}_{50}$ (from 22 to $43 \mathrm{~cm}$, according to ICES [2015]).

To fit the results into the age-structured dynamics of the simulation model, the selectivity-at-length curves were transformed to age using the Von Bertalanffy growth model (the Stock Synthesis III assessment model; Methot and Wetzel 2013) employed by the ICES assessment working group for hake (ICES 2014). The results of applying this procedure are presented in Figure 3.

\section{The simulation model}

A model coupled in all its dimensions (economic, biological and social) is required to perform the impact assessment of the change in the MMS. Economic results are related to the stock productivity, which can change depending on the retention pattern. Moreover, the stock productivity is also related to fishing effort. For example, if one fleet stops fishing, the overall pro-

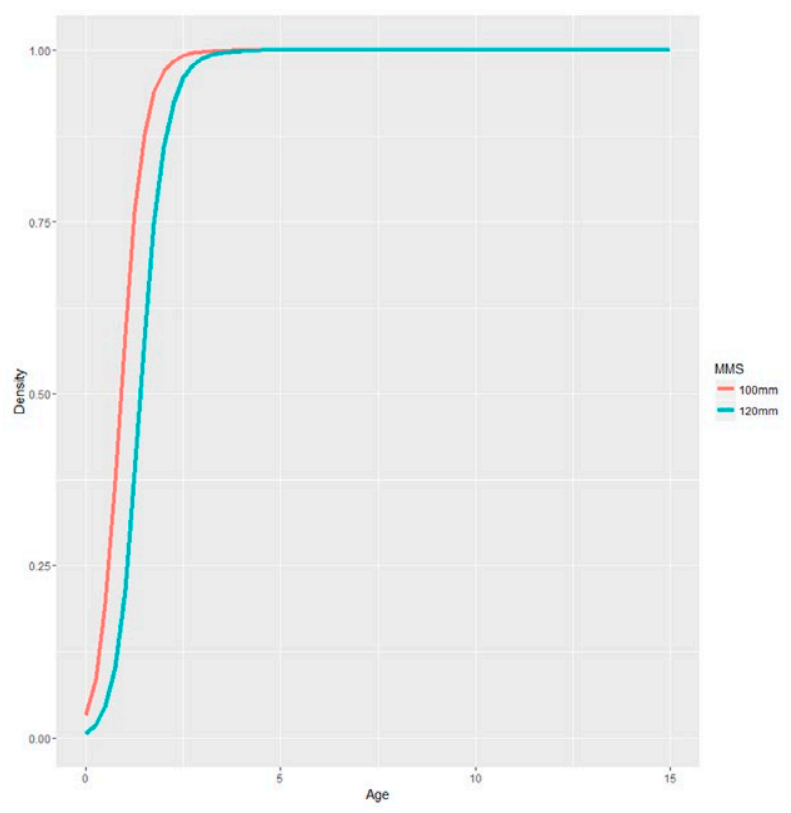

Fig. 3. - Selectivity curves for the pair trawlers using a 100-mm and 120-mm MMS

ductivity of the stock will change, simply because of the average selectivity changes.

The model used was FLBEIA (Garcia et al. 2013, Prellezo et al. 2016), developed in $\mathrm{R}$ ( $\mathrm{R}$ Core Team 2014). The model projects several fleets and the likely effects on stock dynamics under different management scenarios.

\section{Economic conditioning and model}

Pair trawlers were economically conditioned using AZTI data sources obtained through the Data Collection Framework of the EU (EC 2008). The data combine information from log sheets, discard sampling, landing declarations and sale notes (the time series from 2009 to 2013). The cost data of fishing vessels were obtained from the Annual Economic Report on the EU Fishing Fleet (STECF 2014). To adapt these values to the specific conditioning of the case study, the economic figures were weighted by the proportion of pair-trawler vessels and converted into weighted averages for the fleet. The exact values obtained and used in the simulation are reported in Table 1.

Several types of costs were defined: those changing with the effort (variable and fuel costs), those changing with the value of landings (crew costs); and those changing with the number of vessels (fixed, capital and depreciation costs). There are also other costs associated with the LO. Under this regulation, each trip retains more fish than without LO. Therefore, more storage boxes might be required, and the refrigeration facilities of the vessels must be suitable for storing them.

The storage requirements per trip were calculated for boxes of $12 \mathrm{~kg}$. If the maximum number of boxes that can be stored in a fishing unit is higher than the needs, the additional costs will be zero. If not, the additional trips must be evaluated at a variable cost (changing with the effort, if more trips can be made to catch 
Table 1. - Cost data of the Spanish pair trawlers: average. Data source: AER (2014).

\begin{tabular}{|c|c|c|c|c|c|}
\hline Variable & Pair trawlers & Units & Variable & Pair trawlers & Units \\
\hline Fuel Cost & 1240 & $€ /$ days & Capital Cost & 64438 & $€ /$ vessel/year \\
\hline Crew Cost & $33 \%$ & $\%$ of the fishing income & Depreciation & 20952 & $€ /$ vessel/year \\
\hline Variable Cost & 875 & $€ /$ days & Max. days & 150 & days \\
\hline Fixed Cost & 15449 & $€ /$ vessel/year & Employment (full-time equivalent) & 11 & per vessel \\
\hline
\end{tabular}

Table 2. - Hake average ex-vessel prices for the Spanish trawling fleet (2009-2013). Data source: AZTI database.

\begin{tabular}{|c|c|c|c|c|c|}
\hline Code & Common name & Scientific name & Stock & Age & Average price \\
\hline HKE & Hake & Merluccius merluccius & VI, VII, VIIIabd & $<3$ & $€ 2.27$ \\
\hline HKE & Hake & Merluccius merluccius & VI, VII, VIIIabd & 3 & $€ 2.16$ \\
\hline HKE & Hake & Merluccius merluccius & VI, VII, VIIIabd & 4 & $€ 2.07$ \\
\hline HKE & Hake & Merluccius merluccius & VI, VII, VIIIabd & $>4$ & $€ 2.89$ \\
\hline $\mathrm{OTH}$ & Others & Others & - & all & $€ 1.96$ \\
\hline
\end{tabular}

the same amount) or at the market price if the catch is smaller (more trips cannot be made due to a physical limit).

All fleets that cause hake fishing mortality were included in the model. For the projection, the fleet fishing effort was kept constant, except for the Spanish pair trawlers operating in the Bay of Biscay, as explained below.

The relationship between the hake population and the catch was analysed in biomass. The catch and effort relationship was based on a Schaefer production model (Schaefer 1954) at the age level.

$$
\mathrm{h}_{\mathrm{a}}=\mathrm{q}_{\mathrm{a}} \mathrm{EX}
$$

Equation 3 describes the catch of hake (h) at age (a) as a function of its catchability coefficient (q), which was also calculated at the age level, the biomass of hake $(\mathrm{X})$ at the age level and the effort exercised by the fleet on fishing days (E). Throughout the projection, the pairtrawler effort was limited by the TAC share of hake. This share was calculated (based on the average for 20112013) as approximately $8 \%$, as mentioned previously. It was assumed that the remaining hake was caught by the "other" fleets, according to their catch share.

Hake ex-vessel prices were obtained from the sale sheets of the fleet using averages from 2009 to 2013 (Table 2) with a coverage of $100 \%$. The commercial categories were converted into ages on the basis of expert knowledge. The price-age structure follows a "U" shape: "small" individuals (under the age of 3 or $67 \mathrm{~cm}$ long) and "big" individuals (over the age of 4 or $75 \mathrm{~cm}$ long) have higher prices than medium-sized individuals. This result was validated in the interviews with the skippers. They argued that the higher prices for small and large individuals were due to market preferences. For the projection, the prices by age were considered constant, although the average price could change due to the different size compositions of the landings. This is a reasonable assumption, given that the stock is currently close to the $\mathrm{F}_{\mathrm{MSY}}$ (the fishing mortality consistent with achieving MSY). This implies that for the Harvest Control Rule (HCR) used, no big changes in TAC are expected. However, it should be considered that the prices used in the simulation could not clear the market. Finally, for the "other" stock, an average price was calculated (Table 2).

\section{Biological conditioning and model}

The simulation used age-structured dynamics, and the data necessary to condition the model were taken from the ICES assessment working group report and from the results of the assessment modelling conducted by this group (ICES 2014). The stock-recruitment (S/R) relationship used was a Bayesian segmented regression (Butterworth and Bergh 1993). The selection was kept consistent with the methodology used by ICES to estimate the reference points of this stock (ICES 2014). The population was projected by combining this $\mathrm{S} / \mathrm{R}$ with an exponential survival equation (Quinn and Deriso 1989).

Stochasticity was only introduced in the S/R of hake. A lognormal multiplicative error around the S/R curve (with a median equal to one and a coefficient of variation equal to the one observed in the historical period) was used. Two hundred and fifty iterations were run. No more uncertainties were considered.

\section{Management conditioning and model}

The reference point for hake was $\mathrm{F}_{\mathrm{MSY}}$, which in the case of hake is 0.27 (ICES 2014). The TAC advice was generated using the HCR provided by ICES in the framework of the MSY (ICES 2012). This HCR is based on three reference points: $\mathrm{F}_{\mathrm{MSY}}$ (as explained before), the $\mathrm{B}_{\text {trigger }}$ (the biomass that triggers a specific stock recovery action) set at $46000 \mathrm{t}$, and $\mathrm{B}_{\text {lim }}$ (the level of spawning stock biomass, SSB, below which the recruitment might be impaired) set at $33000 \mathrm{t}$. The HCR advises $F_{\text {MSY }}$ unless the SSB falls below $B_{\text {trigger }}$ but remains above $\mathrm{B}_{\text {lim. }}$. If $\mathrm{SSB}$ falls below $\mathrm{B}_{\text {trigger }}$, the fishing mortality advised is reduced in such a way that the biomass recovers the $\mathrm{B}_{\text {trigger }}$ level. Finally, if the biomass falls below $\mathrm{B}_{\text {lim }}$, the TAC advised will be zero.

The "other" stock accounts for the catches of species different from hake. These catches were considered proportional to the effort deployed (using Eq. 3) by the fleet, assuming an arbitrary "large" added biomass. This assumption was expected to have a low impact on the results, given that hake constitutes $90 \%$ of the catch of this fleet.

Perfect implementation of the management advice was assumed. In the projection the LO started in the year 2016, and no exemptions to this LO were introduced. 


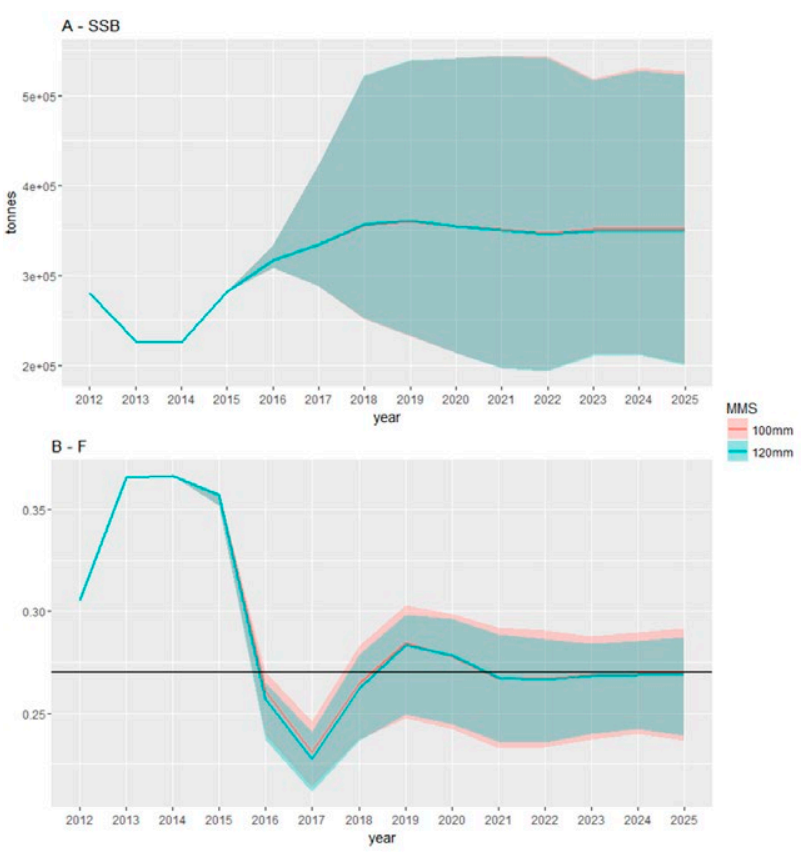

Fig. 4. - Spawning Stock Biomass (SSB) and Fishing mortality (F) evolution under the two different MMS scenarios for pair trawlers. The lines represent the medians. Ninety percent of the iterations fall within the shaded areas. The limits of the shaded areas represent the $5 \%$ and $95 \%$ confidence intervals.

\section{RESULTS}

\section{Changes in the productivity of the stock}

Selectivity changes are likely to alter the productivity of the stock. Even if the removal quantities are similar, their different age compositions could change the age distribution in the stock. In particular, young individuals tend to have higher growth rates (Mellon-
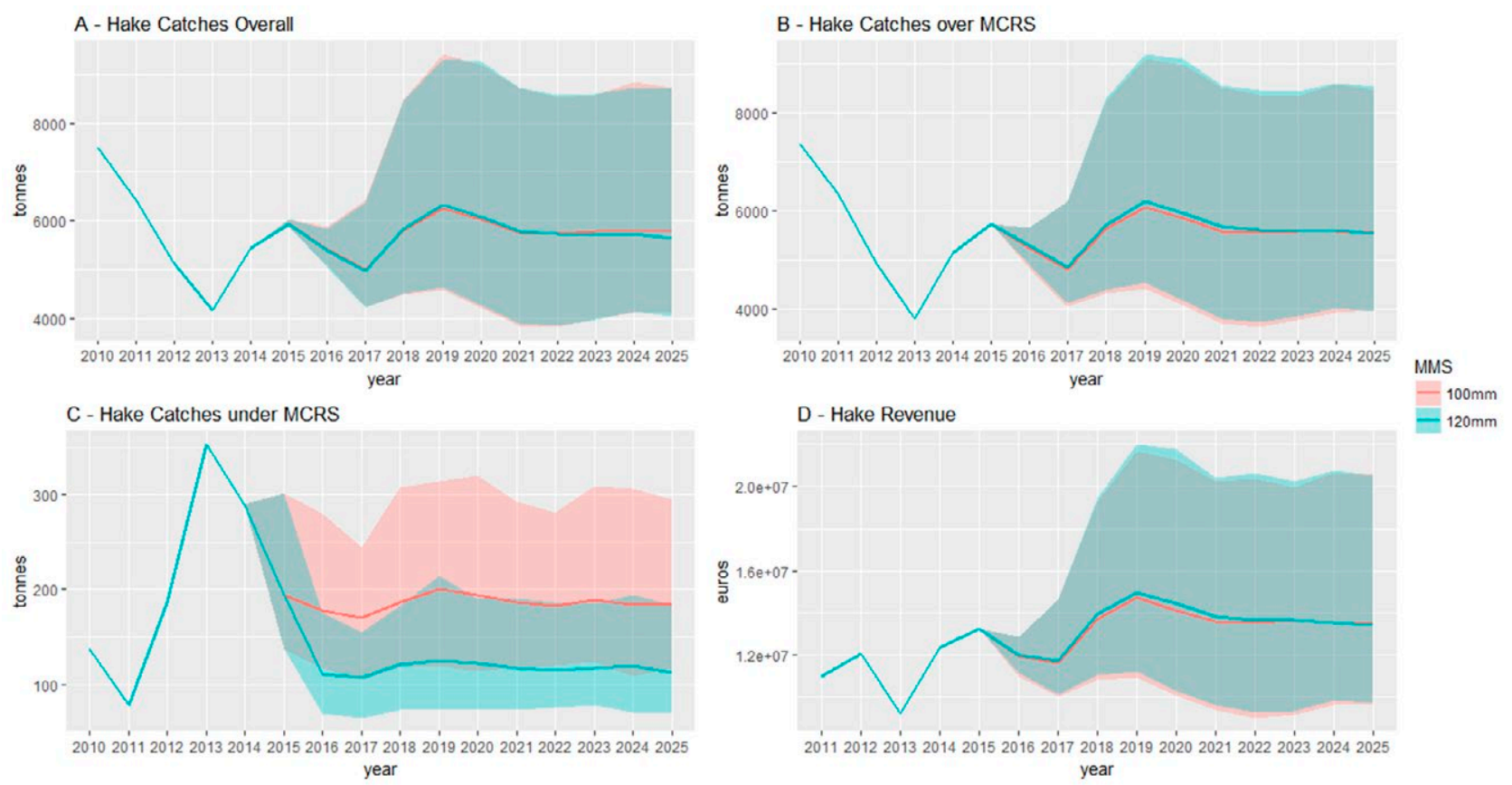

Fig. 5. - Total hake catches, their size distribution (over or under the MCRS) and their market value for pair trawlers under the two MMS scenarios. The lines represent the medians. Ninety percent of the iterations fall within the shaded areas. The limits of the shaded areas represent the $5 \%$ and $95 \%$ confidence intervals.
Duval et al. 2010). Thus, if the average retention size is increased, the productivity of the stock is likely to rise. This hypothesis was tested in the simulation.

Figure 4A shows no differences in the evolution of the stock for the MMS of 100 and $120 \mathrm{~mm}$. This is because the selectivity change only affects $8 \%$ of the hake catches. Thus, the increase in the MMS from 100 to $120 \mathrm{~mm}$ did not have a significant impact on the stock biotic potential.

\section{Changes in catches and landings of hake}

Though the evolution of SSB and fishing mortality did not change during the simulation (Fig. 4B), there were some changes in total catches of hake and in the size distribution of these catches (Fig. 5B, C).

In this fleet, the necessary effort to catch its share of hake (i.e. the quota) was not constrained by the capacity. As a result of the obligation to retain all the catches, extra storage was required (10\% increase in the number of boxes). During an average trip, these fishing units catch approximately $30 \mathrm{t}$ of fish (2500 boxes), with a maximum of $59 \mathrm{t}$ (4900 boxes). The refrigeration capacity of one vessel is around $50 \mathrm{t}$ (4000 boxes); the fishing unit has a refrigeration capacity of $100 \mathrm{t}$. This shows that the refrigeration storage capacity (meeting the safety requirements) does not limit the fishing effort within one trip.

Thus, the number of trips required to catch the TAC share were the same for 100- and 120-mm MMS. It also meant that the overall catches of hake were the same for these two mesh sizes (Fig. 5A). However, there was a difference between size compositions of the catches. The 120-mm MMS gear produced smaller catches of individuals below the MCRS (Fig. 5C). For the overall simulation period (2016-2020), these

B - Hake Catches over MCRS 


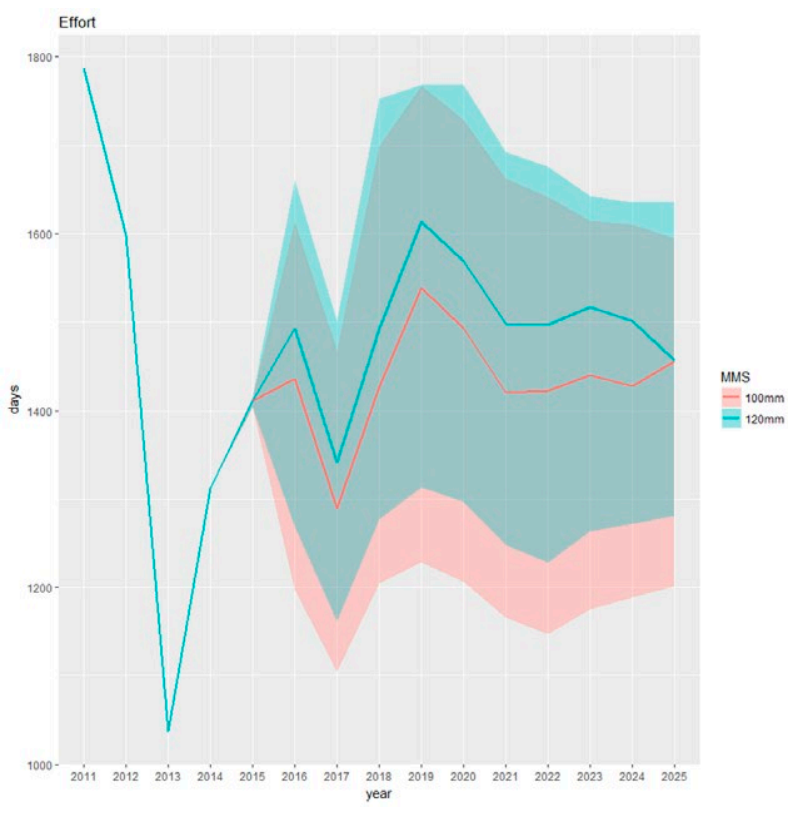

Fig. 6. - Fishing effort (fishing days) for pair trawlers under the two MMS scenarios. The lines represent the medians. Ninety percent of the iterations fall within the shaded areas. The limits of the shaded areas represent the $5 \%$ and $95 \%$ confidence intervals.

catches were reduced by $37 \%$. Figure $5 \mathrm{C}$ shows that the landings of hake that could be sold for direct human consumption increased by $1.4 \%$ when $120-\mathrm{mm}$ MMS were used compared with the 100-mm MMS. Furthermore, as the size structure of these landings was affected, the average price for 120-mm MMS catches was $0.5 \%$ higher than the price of catches conducted using 100-mm MMS gear. The use of 120-mm MMS raised the gross revenues (ex-vessel prices multiplied by the landings) by $2 \%$ (Fig. $5 \mathrm{D})$.
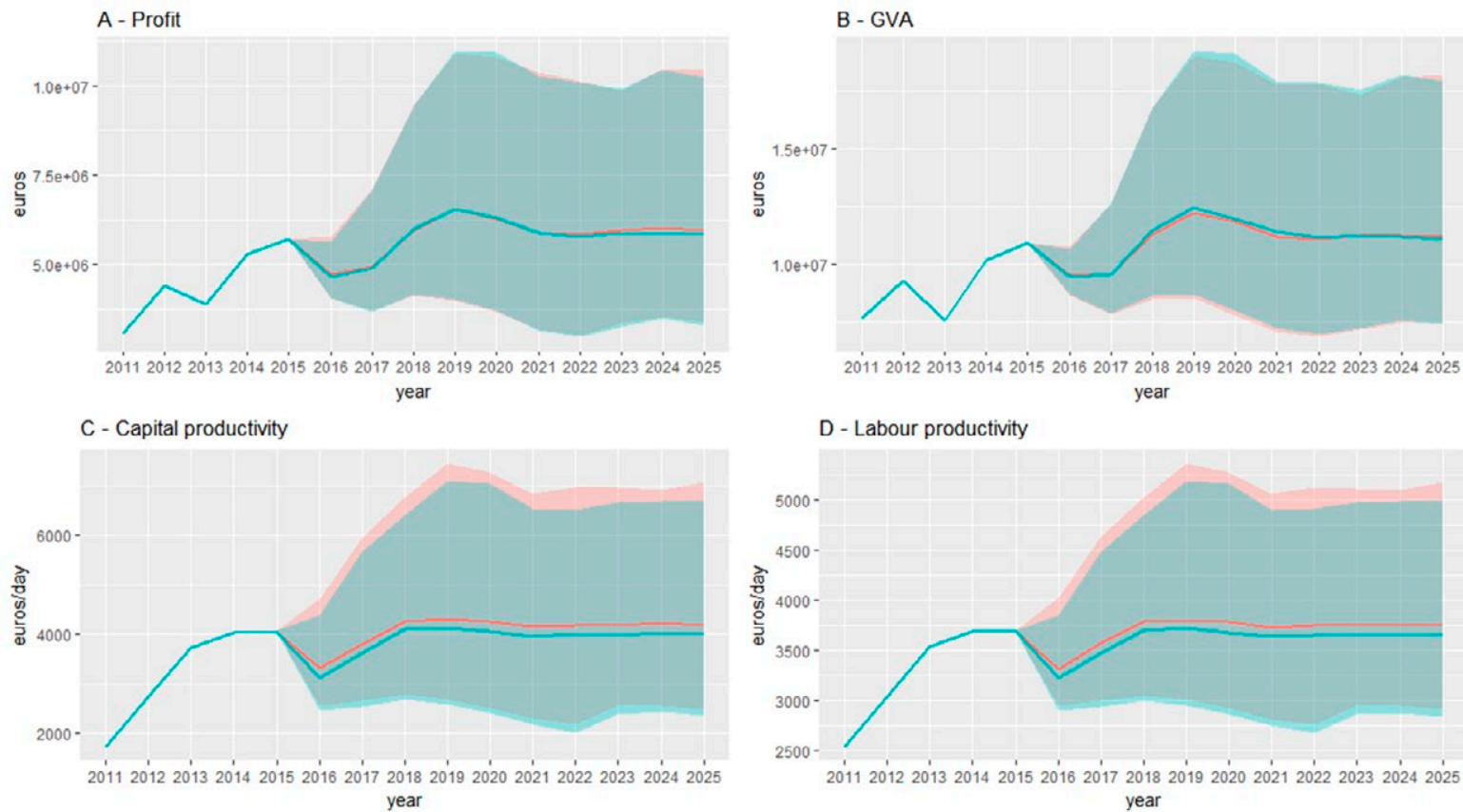

Fig. 7. - Profit, gross value added (GVA), capital productivity and labour productivity of pair trawlers under the two MMS scenarios. The lines represent the medians. Ninety percent of the iterations fall within the shaded areas. The limits of the shaded areas represent the $5 \%$ and lines represent the medians. Ninety percent of the iterations fall within the shaded are
$95 \%$ confidence intervals.

However, fishing with 120-mm MMS nets required an increased level of effort (Fig. 6) because of the lower overall retention of the net. To obtain catches of similar size to those of 100-mm MMS, the effort had to be increased on average by $4.5 \%$ (for the same number of vessels for the period 2016-2020).

\section{Changes in the financial performance of the fleet}

Figure 5A shows that the catches of hake are the same for the two MMSs. The landings of hake destined for human consumption are higher for 120- than for 100-mm MMS (Fig. 5B). Therefore, the gross revenues will also be higher. However, as can be seen in Figure 6 , this result is obtained at the cost of an increased fishing effort, which implies an increase in variable costs. To determine which of these two factors has a stronger effect, two economic indicators were used: gross value added (GVA) and gross profit. GVA quantifies the value that a fishery is adding to the economy. It is comprised of the compensations received by the crew and by the capital (gross profit). The results for these two indicators are presented in Figure 7A and B.

The simulations showed that GVA was larger for 120-mm MMS than for 100-mm MMS. This causes an increase in the gross revenue, which is higher for 120mm MMS net use (Fig. 5D). However, variable costs of the effort required to obtain these landings (crew costs, fuel costs and other variables costs, Table 1) were also higher for the larger MMS. The overall result shows that the increase in revenue is sufficient to compensate for the extra costs, generating an overall increase in the GVA of $1.5 \%$ per year. The crew compensation will also increase because they receive a percentage of the gross revenue. Overall, the use of 120-mm MMS resulted in a crew share increase of $2 \%$ per year.

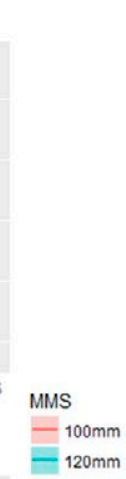


The other component of GVA is the capital compensation, which can be illustrated using profit as an indicator. Profit does not change when the $120-\mathrm{mm}$ MMS is used (Fig. 7A), because a third of the extra gross revenue goes, through the crew share, to the crew. Thus, from the point of view of the capital owner, it is not worth increasing the MMS, or at least there are no financial incentives for this change.

The productivity of fishing effort should also be considered. Capital productivity, measured in terms of the gross profit per fishing day, was 5\% lower for 120mm MMS than for 100-mm MMS (Fig. 7C). Crew productivity (crew compensation per fishing day) was also lower (2.5\%) for the larger MMS (Fig. 7D). Though the total crew compensation is higher when using this MMS, it is obtained by increasing the number of fishing days, with a reduced compensation per day.

In summary, the results show that increasing the MMS from 100 to $120 \mathrm{~mm}$ does not change the stock biotic potential, at least when this increase is implemented in the fleet studied. However, the productivity of the effort is reduced, in terms of both catches per unit of effort and the GVA and profit per unit of effort. The total capital compensation was unchanged, so there were no private economic incentives to implement the MMS change. The MMS increase produced more hake landings above MCRS and higher average ex-vessel prices of hake, which created an increase in revenues and $\mathrm{GVA}$.

\section{DISCUSSION}

\section{Consultation with skippers}

As pointed out by Graham et al. (2007), a gear design solution might be more acceptable to fishers than a spatial or temporal closure. The answers obtained from the interviews with the skippers are in agreement with this notion. The MMS increase, as a way to improve the selectivity of the fishing gear, is a measure that can be implemented when the choke effect is caused by the size composition and not by the species conflict. However, increasing the selectivity of the gear is not straightforward. For example, in the same fishing area, the inclusion of a top square mesh panel has not produced significant changes in the size composition of the catches (Alzorriz et al. 2016). Furthermore, the results from the simulation show no capital-based incentives to increase the MMS.

\section{Biotic potential}

Before an economic impact assessment, an evaluation of the effects of a change in selectivity on the biotic potential of the stock should be conducted. This evaluation should be integrated and coupled with the economic analysis. The result of the simulation presented here shows that, from the fishery community point of view, there would be no evolutionary change due to the new selection pattern. The study of Hilborn and Minte-Vera (Hilborn and Minte-Vera 2008) shows that selectivity is not the main aspect of the growth of the stocks. The results of the current simulation confirmed this observation; however, it must be taken into account that only $8 \%$ of the fishing mortality was considered.

The simulation did not deal with the impact on the ecosystem. Gear-related conservation measures assume that the escaping fish survive and support the relevant population. However, there are no reliable estimates of post-capture survival of hake (Suuronen and Sardà 2007). The overall impact on the ecosystem is not easy to anticipate. Neither the changes in the ecosystem productivity (Sardà et al. 2015) nor the effects of these changes on the fleet productivity (Garcia et al. 2011, 2012) predict ecological perturbations in a precise way. Further research in this field is urgently needed.

\section{Fishing effort}

In the analysed fleet, an increase in MMS reduced the efficiency of the system (in terms of catch per unit of effort). The desired effect of the regulation is to change the size distribution by reducing the catches of individuals under MCRS. This change should also increase the average price. This was, indeed, the case in our simulation, although this result was the consequence of the change in the MMS and not its cause (Asche et al. 2015). Nevertheless, this result might create an incentive for using gears with increased selectivity.

In the simulation presented here, a rise in selectivity implies a lower retention of individuals below the MCRS of hake. The overall effect is that more of the landings are destined for human consumption but at the cost of increased fishing effort. When more effort is exerted, two possible limits have to be considered. The first limit is a capacity ceiling (no more fishing days are available, or no more vessels can be made). We did not observe this problem in the current simulation. The second potential limit is associated with the species caught, of which some might be constrained by the LO. In the case analysed, the fleet is "almost" a single-species fleet, so such situation is unlikely. The results show that the fleet using an increased-MMS gear needs more effort to catch their hake quota. No onboard storage limits were observed. However, the storage problems might occur in different fleets, and an increase in the number of trips might be necessary to land the same amount of fish for human consumption.

\section{Economic and financial results of the fishing firms}

The observed $2 \%$ increase in gross revenues clearly differs from the predicted general $10 \%$ to $15 \%$ reduction (Villasante et al. 2016). This discrepancy can be explained by the single-species character of the analysed fleet. However, we also observed an increase in the required fishing effort and, hence, a rise in the variable costs. Overall, the private financial results (profits of the capital owner) are not improved by using a larger MMS. This result has been anticipated by Skonhoft et al. (2012), whose study concludes that a policy enforcing a more selective fishing gear can either reduce or increase the total profitability of the fishery. 
The productivity of the effort was reduced by employing the larger MMS nets. This was true from the point of view of both the capital owner (profit) and the labour force (crew compensation). Furthermore, this result was independent of the investment required to change the MMS and/or the time to amortize this investment. Thus, it seems that there are no private incentives to use the more selective fishing gear. However, some costs associated with the LO were not considered in the simulation. For example, additional landing costs might be incurred by buying the boxes necessary to store the extra fish or the cost of ice to keep the catch fresh. This might be compensated by the extra income from selling the catch under the MCRS. A commercial fishmeal plant was consulted and cited the average price of between 50 and $120 € / t$, depending on the fish quality (freshness and oil percentage of the raw material). At this price level, approximately $10 \%$ of the extra landing costs could be covered. Even if this conclusion might be somewhat speculative, it seems that the additional landing costs observed might result in an underestimate of the perceived private incentives for changing the MMS. Further research is required to analyse this issue.

Finally, the results showed that the GVA and human consumption hake supply increased after the enlargement of the gear MMS. This means that society has the potential capacity to compensate the productivity loss of the owners of the labour and the capital.

\section{CONCLUSIONS}

Here, we performed a bioeconomic impact assessment of an MMS increase for a case study in the Atlantic Area. It should be noted, however, that the MCRS regulations will have a more global effect in other EU areas such as the Mediterranean, where the TAC is not used as a general fishery management instrument, and the MCRS is the main component of the LO. The simulation showed no private incentives for increasing the MMS. However, this conclusion cannot necessarily be extrapolated to other areas or to other fleets. Other case-specific studies must be conducted to reach a detailed understanding of the subject. The lack of private incentives should not discourage society from supporting the increase in the selective fishing activities. From the social perspective, there is room for incentives that increase the selectivity of the gear, at least in the fleet analysed here. These incentives can be created by penalizing the lower selectivity of the 100-mm MMS or rewarding (for example, with a higher quota or effort possibilities) the use of a more selective gear. One such example is the bonus provided to some vessels in the fully documented fishery trials of Danish fisheries (Kindt-Larsen et al. 2011).

\section{ACKNOWLEDGEMENTS}

This work was partially financed by the EU H2020 project Discardless (Grant Agreement No 633680), the REdDisc project and the Basque Government-funded project MULTIPLAN. I.C. has also benefited from a grant from the Training of Technologists Programme of the Department of Economic Development and Competitiveness of the Basque Government. This publication reflects the views of the authors only and none of the funding parties can be held responsible for any use which may be made of the information contained therein. This is contribution 815 from the Marine Research Division (AZTI-Tecnalia).

\section{REFERENCES}

Alzorriz N., Arregi L., Herrmann B., et al. 2016. Questioning the effectiveness of technical measures implemented by the Basque bottom otter trawl fleet: Implications under the EU landing obligation. Fish. Res. 175: 116-126. https://doi.org/10.1016/j.fishres.2015.11.023

Arreguín-Sánchez F. 1996. Catchability: a key parameter for fish stock assessment. Rev. Fish Biol. Fish. 6: 221-242. https://doi.org/10.1007/BF00182344

Asche F., Chen Y., Smith M.D. 2015. Economic incentives to target species and fish size: prices and fine-scale product attributes in Norwegian fisheries. ICES J. Mar. Sci. 72: 733-740. https://doi.org/10.1093/icesjms/fsu208

Brookhuis N. 2015. Swimming against the current? An exploration of the conditions for a successful implementation of the landing obligation in fisheries policy. Utrecht Univ.

Butterworth D., Bergh M. 1993. The development of a management procedure for the South African anchovy resource. Can. Spec. Publ. Fish. Aquat. Sci. 120: 83-100.

Cotter A., Pilling G. 2007. Landings, logbooks and observer surveys: improving the protocols for sampling commercial fisheries. Fish Fish. 8: 123-152 https://doi.org/10.1111/j.1467-2679.2007.00241.x

EC. 2008. Council Regulation (EC) No 199/2008 of 25 February 2008 concerning the establishment of a Community framework for the collection, management and use of data in the fisheries sector and support for scientific advice regarding the Common Fisheries Policy.

Escapa M., Prellezo R. 2003. Fishing Technology and Optimal Distribution of Harvest Rates. Environ. Resour. Econ. 25: 377-394. https://doi.org/10.1023/A:1024478107203

EU. 2013. Regulation (EU) No 1380/2013 of the European Parliament and of the Council of 11 December 2013 on the Common Fisheries Policy, amending Council Regulations (EC) No 1954/2003 and (EC) No 1224/2009 and repealing Council Regulations (EC) No 2371/2002 and (EC) No 639/2004 and Council Decision 2004/585/EC, Official Journal of the European Union, Brussels.

FAO. 1996. Technical consultation on reduction of wastage in fisheries, Tokyo, 28 October - 1 November 1996. FAO Fisheries Report No. 547, Rome, 27 pp.

Garcia D., Prellezo R., Santurtun M., et al. 2011. Winners and losers of a technical change: A case study of long-term management of the Northern European Hake. Fish. Res. 110: 98-110. https://doi.org/10.1016/j.fishres.2011.03.018

Garcia S.M., Kolding J., Rice J., et al. 2012. Reconsidering the Consequences of Selective Fisheries. Science 335: 1045-1047. https://doi.org/10.1126/science.1214594

Garcia D., Urtizberea A., Diez G., et al. 2013. Bio-economic management strategy evaluation of deepwater stocks using the FLBEIA model. Aquat. Living Resour. 26: 365-379. https://doi.org/10.1051/alr/2013069

Graham N., Ferro R.S.T., Karp W.A., et al. 2007. Fishing practice, gear design, and the ecosystem approach-three case studies demonstrating the effect of management strategy on gear selectivity and discards. ICES J. Mar. Sci. 64: 744-750. https://doi.org/10.1093/icesjms/fsm059

Heikinheimo O., Setälä J., Saarni K., et al. 2006. Impacts of meshsize regulation of gillnets on the pikeperch fisheries in the Archipelago Sea, Finland. Fish. Res. 77: 192-199. https://doi.org/10.1016/j.fishres.2005.11.005

Herrmann B. 2005. Effect of catch size and shape on the selectivity of diamond mesh cod-ends: II. Theoretical study of haddock selection. Fish. Res. 71: 15-26. https://doi.org/10.1016/j.fishres.2004.08.021

Hilborn R., Minte-Vera C.V. 2008. Fisheries-induced changes in growth rates in marine fisheries: are they significant? Bull. Mar. 
Sci. 83: 95-105

Hovgård H., Lassen H. 2000. Manual on estimation of selectivity for gillnet and longline gears in abundance surveys. Food and Agriculture Org.

ICES. 2012. WKFRAME-3. Report of the Workshop on Implementing the ICES Fmsy Framework. Copenhaguen, Denmark.

ICES. 2014. Report of the Working Group for the Bay of Biscay and the Iberian waters Ecoregion (WGBIE), 7-13 May 2014, Lisbon, Portugal. ICES CM 2014/ACOM:11, 714 pp.

ICES. 2015. Second Interim Report of ICES-FAO Working Group on Fishing Technology and Fish Behaviour (WGFTFB), 4-7 May 2015, Lisbon, Portugal. ICES CM2015/SSGIEOM:22, $183 \mathrm{pp}$.

IEO. 2006. Instituto Español de Oceanografía. Informe Pesca Experimental RAI-AP-10/2006, 32pp.

Kindt-Larsen L., Kirkegaard E., Dalskov J. 2011. Fully documented fishery: a tool to support a catch quota management system. ICES J. Mar. Sci. 68: 1606-1610. https://doi.org/10.1093/icesims/fsr065

Macher C., Guyader O., Talidec C., et al. 2008. A cost-benefit analysis of improving trawl selectivity in the case of discards: the Nephrops norvegicus fishery in the Bay of Biscay. Fish. Res. 92: 76-89. https://doi.org/10.1016/j.fishres.2007.12.021

Mellon-Duval C., De Pontual H., Métral L., et al. 2010. Growth of European hake (Merluccius merluccius) in the Gulf of Lions based on conventional tagging. ICES J. Mar. Sci. 67: 62-70. https://doi.org/10.1093/icesjms/fsp215

Methot R.D., Wetzel C.R. 2013. Stock synthesis: a biological and statistical framework for fish stock assessment and fishery management. Fish. Res. 142: 86-99. https://doi.org/10.1016/j.fishres.2012.10.012

Ozbilgin H., Wardle C.S. 2002. Effect of seasonal temperature changes on the escape behaviour of haddock, Melanogrammus aeglefinus, from the codend. Fish. Res. 58: 323-331. https://doi.org/10.1016/S0165-7836(01)00394-0

Prellezo R., Carmona I., Garcia D. 2016. The bad, the good and the very good of the landing obligation implementation in the Bay of Biscay: A case study of Basque trawlers. Fish. Res. 181: 172-185.

https://doi.org/10.1016/j.fishres.2016.04.016

Quinn R.B., Deriso T.J.I. 1989. Quantitative fish dynamics, Oxford University Press.
R Core Team. 2014. R: A Language and Environment for Statistical Computing. R Foundation for Statistical Computing. Austria. Vienna.

Rochet M.-J., Arregi L., Fonseca T., et al. 2014. Demersal discard atlas for the South Western Waters, $121 \mathrm{pp}$.

Sardà F., Coll M., Heymans J.J., et al. 2015. Overlooked impacts and challenges of the new European discard ban. Fish Fish. 16: 175-180. https://doi.org/10.1111/faf.12060

Schaefer M. 1954. Some aspects of the dynamics of populations important to the management of commercial marine fisheries. Bull. I-ATTC 1: 25-56.

Schrope M. 2010. What's the catch? Nature 465: 540-542. https://doi.org/10.1038/465540a

Sigurđardóttir S., Stefánsdóttir E.K., Condie H., et al. 2015. How can discards in European fisheries be mitigated? Strengths, weaknesses, opportunities and threats of potential mitigation methods. Mar. Policy 51: 366-374. https://doi.org/10.1016/j.marpol.2014.09.018

Simons S.L., Döring R., Temming A. 2015. Modelling fishers' response to discard prevention strategies: the case of the North Sea saithe fishery. ICES J. Mar. Sci. 72: 1530-1544. https://doi.org/10.1093/icesjms/fsu229

Skonhoft A., Vestergaard N., Quaas M. 2012. Optimal harvest in an age structured model with different fishing selectivity. Environ. Resour. Econ. 51: 525-544. https://doi.org/10.1007/s10640-011-9510-X

STECF (Scientific, Technical and Economic Committee for Fisheries). 2014. The 2014 Annual Economic Report on the EU Fishing Fleet (STECF-14-16). Publications Office of the European Union, Luxembourg, EUR 26901 EN, JRC 92507, 363 pp.

Suuronen P., Sardà F. 2007. The role of technical measures in European fisheries management and how to make them work better. ICES J. Mar. Sci. 64: 751-756. https://doi.org/10.1093/icesjms/fsm049

Tschernij V., Holst R. 1999. Evidence of factors at vessel-level affecting codend selectivity in Baltic cod demersal trawl fishery. ICES CM, 2.

Villasante S., Pita C., Pierce G.J., et al. 2016 To land or not to land: How do stakeholders perceive the zero discard policy in European small-scale fisheries? Mar. Policy 71: 166-174. https://doi.org/10.1016/j.marpol.2016.05.004 